\title{
EDUCATIONAL STRUCTURE OF REFUGEES
}

\author{
Katja Stammen ${ }^{1}$ \\ ${ }^{1}$ Department of Business and Economics, Mendel University in Brno, Zemědělská 1, 61300 Brno, Czech Republic
}

Link to this article: https://doi.org/10.11118/actaun.2021.027

Received: 6. 3. 2019, Accepted: 7. 4. 2021

To cite this article: STAMMEN KATJA. 2021. Educational Structure of Refugees. Acta Universitatis Agriculturae et Silviculturae Mendelianae Brunensis, 69(2): 281-290.

\begin{abstract}
Since 2015, the Federal Republic of Germany has accepted more than one million refugees. In many cases, the refugee crisis in Germany is seen as an opportunity to compensate for the need for skilled labour. By 2030 there will be a shortage of around 3 million skilled workers. Therefore, this article focuses on the educational structure of refugees in the years 2015-2017. A survey of a total of 687 refugees and a comparative analysis using data from the Federal Office for Migration and Refugees (BAMF) revealed that about 70\% of asylum seekers are of working age. 14\% of the refugees have no formal education. More than 50\% have attended primary and secondary school. Furthermore, $75 \%$ have not undergone any training. Therefore, integrative measures and offers of further education are absolutely necessary. The quality and implementation of these measures are primarily decisive for the success of the integration of refugees into the German labour market.
\end{abstract}

Keywords: refugees, refugee crisis, educational structure, school education, vocational education, training, labour market

\section{INTRODUCTION}

Since 2015, more than one million refugees have sought refuge in the Federal Republic of Germany. The "refugee crisis" poses one of the greatest challenges for Germany and the other member states of the European Union due to the enormous numbers of refugees. However, the refugee crisis is often seen in German politics as an opportunity not only to compensate for population decline, but also to compensate for the need for skilled labour in Germany (Aumüller and Gesemann, 2016).

Skilled workers are defined as persons who have completed at least two years of vocational training or have a recognised academic qualification (BA, 2018, p. 3). According to surveys by the German Institute of Economics in Cologne (IW), two out of three jobs that require vocational training or university studies are already difficult or impossible to fill. The trend continues to rise. For example, a study by Brossardt and Ehrentraut (2015) concludes that a total of three million skilled workers could be lacking in Germany alone by the year 2030 if no countermeasures are taken by industry and politics.

Accordingly, Germany needs qualified workers who can fill the above positions and fit into the given labour market. The aim of this article is therefore to answer the question of what educational structure refugees have from the years 2015-2017 and whether this potential can be integrated into the German labour market. The aim is to gain insight into the extent to which market equilibrium can be guaranteed in order to meet the challenges of the time.

\section{Literature Overview and Stylized Facts}

So far there have been hardly any reliable studies on the educational structure of refugees (both at school and in the workplace) in Germany. The majority of students have so far dealt with the educational opportunities of refugees after their arrival in the Federal Republic of Germany. 


\section{Study of the Federal Office for Migration and Refugees}

As part of the asylum application process, the Federal Office for Migration and Refugees (BAMF), with the help of an interpreter, collects data on the highest level of school education completed and training completed (Rich, 2016; Neske, 2017 and Schmidt, 2018) on a voluntary basis, in addition to the master data of the fugitives. In the meantime, the sample for the years 2015-2017 comprises more than 600,000 persons. With regard to the validity of the data, however, it should be borne in mind that in the case of a purely self-disclosure without the provision of evidence, there is the possibility of strategic response behaviour (ibid.).

In addition to the BAMF survey, the Institute for Employment Research (IAB), the Research Centre of the Federal Office for Migration and Refugees (BAMF-FZ) and the Socioeconomic Panel (SOEP) at the German Institute for Economic Research (DIW Berlin) have been conducting a representative survey of fugitives since 2016 (Brücker et al., 2018, p. 6). The study is scheduled to run until the end of 2019. The longitudinal survey is based on the population of fugitives regardless of their residence status. The data basis for the sample is the Central Register of Foreigners (Brücker et al., 2018, p. 19). The IAB-BAMF-SOEP survey is an annual survey in which around 4,800 fugitives are repeatedly interviewed to ensure the quality of the data (ibid.).

According to BAMF surveys, refugees from the years 2015-2017 have a very young age structure. More than $50 \%$ of the asylum seekers are under 25 years old. The low proportion of female refugees, especially in the age groups up to 44 years, is also striking. Refugees are therefore predominantly male persons of working age. Fig. 1 shows the highest educational institutions attended by refugees.

More than 50\% of refugees from all countries of origin have attended at least primary and secondary
I: Highest level of vocational training of adult asylum seekers (in \%)

\begin{tabular}{|c|c|c|c|}
\hline Form of training & Male & Female & Total \\
\hline No training & 75 & 78 & 76 \\
\hline Company training & 9 & 5 & 7 \\
\hline $\begin{array}{l}\text { Technical college/university, } \\
\text { doctorate }\end{array}$ & 16 & 17 & 17 \\
\hline
\end{tabular}

Source: Brücker et al., 2018, p. 27; Brücker et al., 2016 and own calculations

school. The high proportion of Afghan refugees who have no formal school education is striking. From the numbers of Syrian refugees it can be concluded that there was a functioning school system at least until the outbreak of the war, as they have a high proportion of people who attended a grammar school and a university.

In the case of training, both in enterprises and at universities (Tab. I), a high proportion, 76\%, did not undergo training. The high number of university degrees is striking, accounting for $17 \%$ of the total, with men and women equally well educated in this area.

The above results are supported by data from the Federal Statistical Office's Microcensus 2016 (Statista, 2016, p. 178 f.). According to this, 30.4\% of Syrians, $36.3 \%$ of Iraqis and $37.7 \%$ of Afghans have no formal school leaving certificate (ibid.). The results of the Microcensus also show that $70.3 \%$ of Syrians, $64.7 \%$ of Iraqis and $63 \%$ of Afghans have no completed education (Statista, 2016, p. 202 f.).

\section{Research Deficits}

The problem with the studies presented is that the data on the qualification structure are based exclusively on voluntary data. At this point, corresponding studies would be desirable which survey the qualification structure of refugees on the basis of evidence. In addition, the qualifications

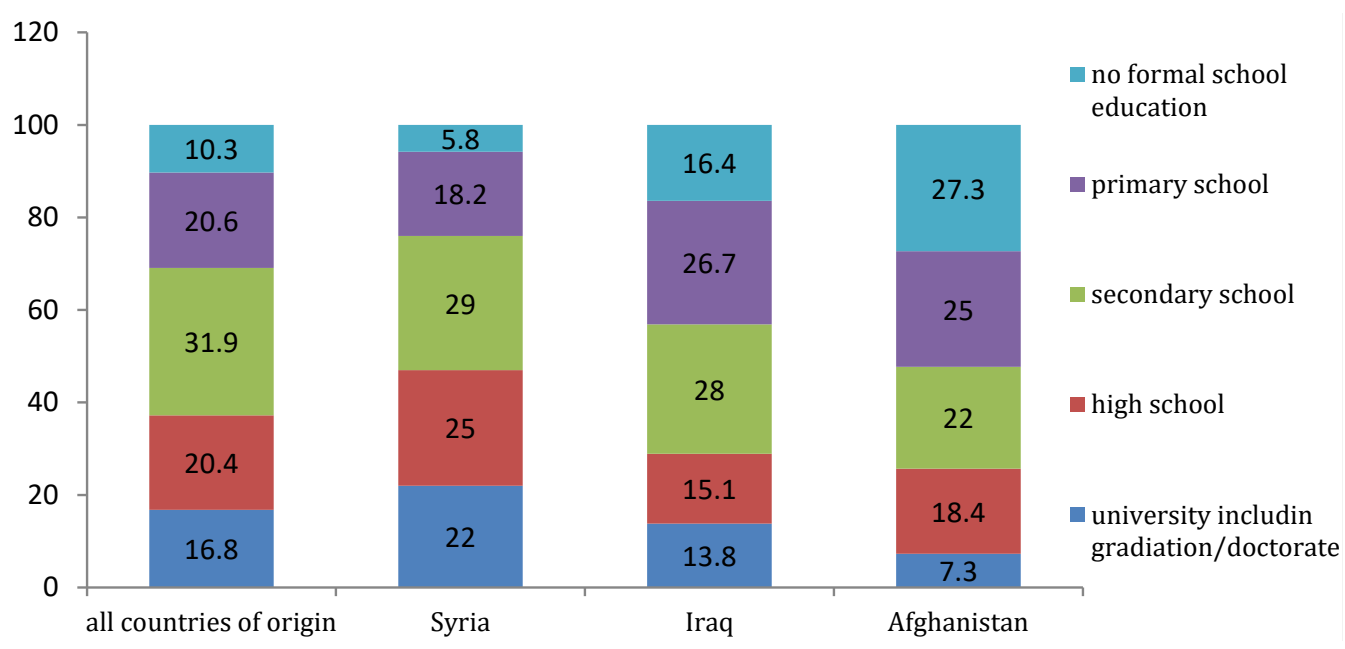

1: Highest number of educational institutions attended by adult asylum seekers (in \%) Source: Rich, 2016, p. 5; Neske, 2017, p. 6 f.; Schmidt, 2018, p. 6 and own calculations 
must be reviewed with regard to recognition in Germany. If a qualification is available, this does not mean that it is also recognized in Germany, as the school and occupational systems in third countries differ considerably from those in Germany.

\section{Summary}

According to BAMF surveys, refugees from the years 2015-2017 are predominantly men of working age. More than 50\% of the refugees from all countries of origin have attended at least primary and secondary school. However, it should be noted that there is also a very high proportion of people who do not have a formal school education. As far as education is concerned, 76\% have not completed any. However, the high proportion of university degrees deserves special mention.

\section{MATERIALS AND METHODS}

The data in the article are based on a quantitative survey of refugees who were admitted to the Federal Republic of Germany between 2015 and 2017. In the period from 01.09.2018 to 10.10.2018 a total of 687 persons with corresponding citizenship were interviewed orally in a structured manner in the following cities: Soest, Lippstadt, Paderborn, Bielefeld, Essen and Bochum. Different cities were considered in particular in order to obtain a larger sample and representativeness. The survey locations were both large cities in the Ruhr area (conurbations) and smaller cities in rural areas. In many aspects relevant to the survey, the interviewees were asked to provide as accurate a picture as possible of the people in the population as a whole.

The refugees were first asked with the help of an interpreter whether they had entered the country between 2015 and 2017. If this question was answered in the negative, the persons were not interviewed any further. Furthermore, only refugees in the age category 18-65 years were asked about their level of qualification. In detail, data were collected on country of origin, gender, age and on school and vocational education and training. With regard to school education, the highest qualification was surveyed in each case. With regard to the validity of the data, however, it should be borne in mind that in the case of a purely self-disclosure, there is a possibility of untruthful statements being made, as no corresponding evidence could be examined in the available data.

Methodologically, a comparative analysis in the form of descriptive statistics was used. The data from the survey were compared with the survey conducted by the Federal Office for Migration and Refugees (BAMF) in order to determine the most accurate possible variance with respect to the population as a whole. All countries of origin as well as the main countries of origin were analysed in a single analysis. These are refugees from Syria, Iraq and Afghanistan. These countries of origin account for $59.1 \%$ of all refugees (Fig. 2).

Contingency tables were used as a method of presentation for analysis purposes. The absolute frequencies of two categorical characteristics were plotted against each other in a table (cross table). In addition, bar charts were used and evaluated using the SPSS statistical software. In the case of simple bar charts, the frequencies of characteristic values of a categorical characteristic are represented visually as bars. Stacked bar charts were used when comparing several groups with respect to a categorical characteristic.

\section{RESULTS}

The structure of the composition of refugee flows by age, gender and qualifications (both academic and professional) is described below. All countries of origin are presented first, followed by the three main countries of origin.

\section{Age and Gender Structure of Refugees from All Countries of Origin}

The age structure of the present sample (survey) is somewhat older than that of the BAMF due to the survey of adult persons (Fig. 3). In this sample, about $63 \%$ of the participants are under 30 years of age,

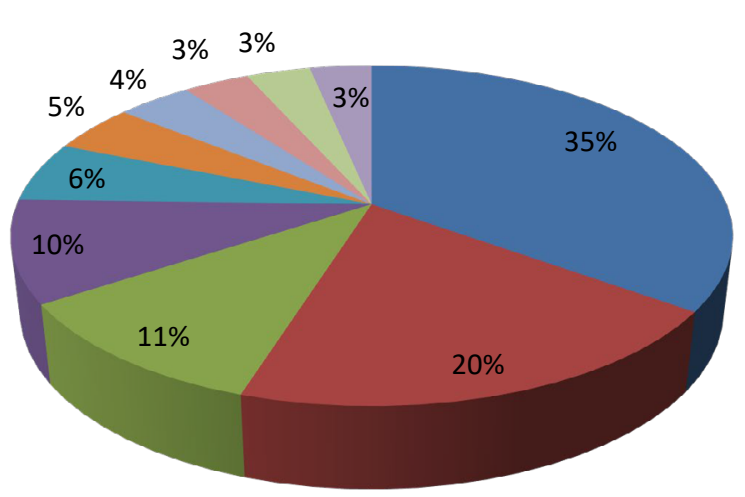

Syria
Iraq
Afghanistan
Albanien
Kosovo
Iran
Eritrea
Guniea
Serbia
Turkey

2: Asylum applications of the top ten nationalities in 2015-2017 (in \%) Source: BAMF, 2015, 2016 and 2017 and own calculations 
which is why it can be regarded as comparatively young. Otherwise, it is similar to the distribution of BAMF data. The frequencies decrease across the age groups before increasing marginally again for the largest age group.

The distribution between the sexes can be found in Tab. II. This shows that the largest inequality between the sexes is in the age group between 40 and 44 years. Here $70.4 \%$ of the participants are men and 29.6\% women. In the BAMF data, this was the group aged between 18 and 24 years with 76\% men and $24 \%$ women. In the surveyed sample, an increase in the proportion of male refugees across the age categories up to 30 and 34 years can be observed. The proportion of men in the age groups 35 and 39 fell by about 7 percentage points to $61.7 \%$, before rising again to $70.4 \%$ in the class of 40 to 44 -year-olds. In the class of over 45 year olds, the gender ratio is comparatively balanced with 58.1\% of men and $41.9 \%$ of women.

\section{Age and Gender Structure of Refugees from Syria, Iraq and Afghanistan}

The age distributions for refugees from Syria, Iraq and Afghanistan can be seen in Figs. 4-6. It can be seen that the country-specific distributions are very similar to the overall distribution.

Among the Iraqi refugees, the higher proportion of people aged 25-29 is conspicuous (Fig. 5). This also applies to Afghan refugees (Fig. 6).

Tab. III below shows the differences in gender age distributions for the three main countries of origin. This shows that the gender distribution of Syrian and Iraqi refugees is comparatively even.

Among the Syrian refugees, the most unequal gender distribution can be found in the group of 40-44 year olds. Here $60 \%$ are men and $40 \%$ women. Among the Iraqis, this is the group of 30-34 year olds. Here about 7 out of 10 Iraqis are male. Among Afghans, this is the group of 40-44 year olds. Only men were interviewed here. In summary, it can thus be stated that the refugees surveyed are predominantly males of working age.

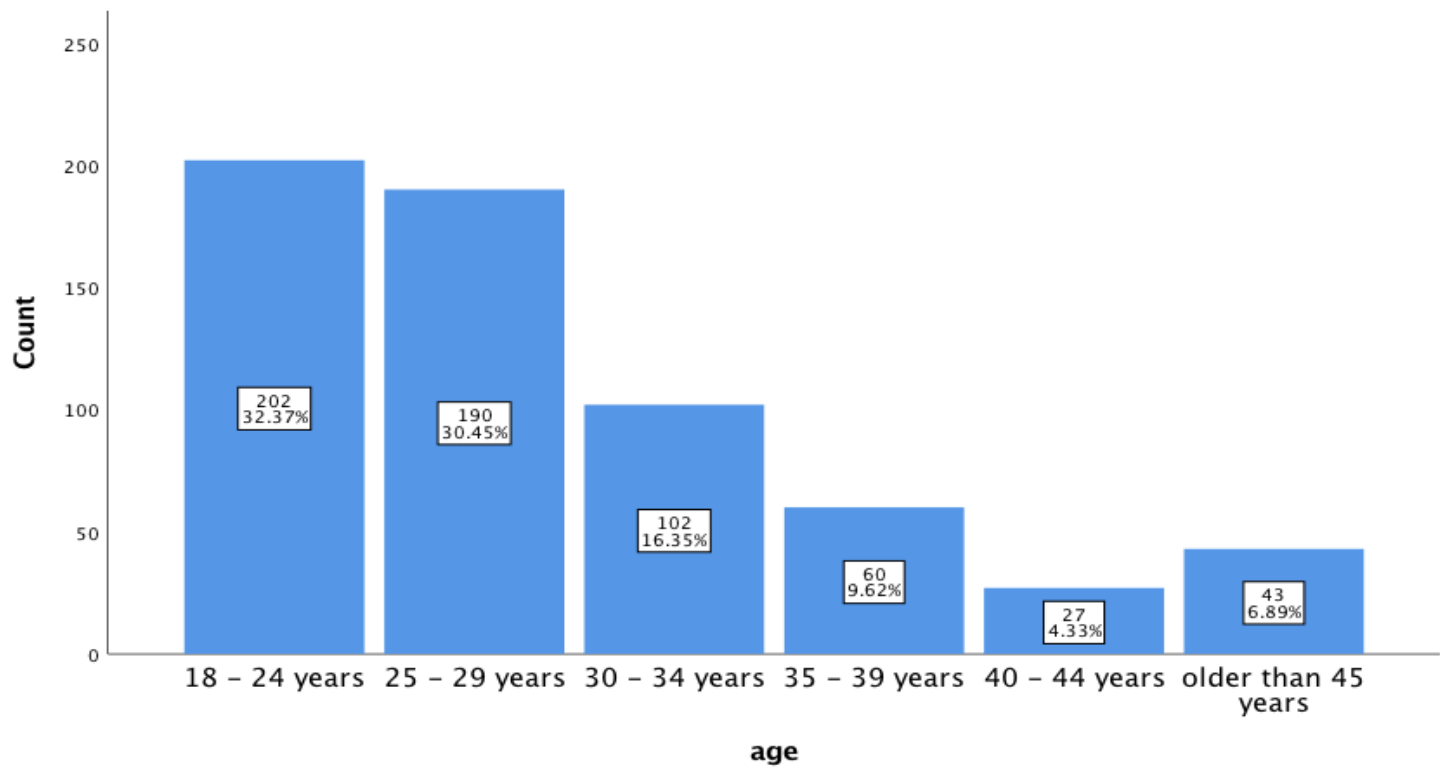

3: Age structure of refugees by gender of countries of origin 2015-2017 (in \%)

Source: author

II: Gender distribution

\begin{tabular}{llccccccc}
\hline \multicolumn{2}{c}{$\begin{array}{c}\text { Sex* age Crosstabulation } \\
\text { age in years }\end{array}$} & 18-24 & 25-29 & 30-34 & 35-39 & 40-44 & 45 & Total \\
\hline \multirow{2}{*}{ Sex male } & Count & 127 & 125 & 70 & 37 & 19 & 25 & 403 \\
& \% within age & $62.9 \%$ & $65.8 \%$ & $68.6 \%$ & $61.7 \%$ & $70.4 \%$ & $58.1 \%$ & $64.6 \%$ \\
\hline \multirow{2}{*}{ Sex female } & Count & 75 & 65 & 32 & 23 & 8 & 18 & 221 \\
& \% within age & $37.1 \%$ & $34.2 \%$ & $31.4 \%$ & $38.3 \%$ & $29.6 \%$ & $41.9 \%$ & $35.4 \%$ \\
\hline \multirow{2}{*}{ Total } & Count & 202 & 190 & 102 & 60 & 27 & 43 & 624 \\
\hline & \% within age & $100 \%$ & $100 \%$ & $100 \%$ & $100 \%$ & $100 \%$ & $100 \%$ & $100 \%$ \\
\hline
\end{tabular}

Source: author 


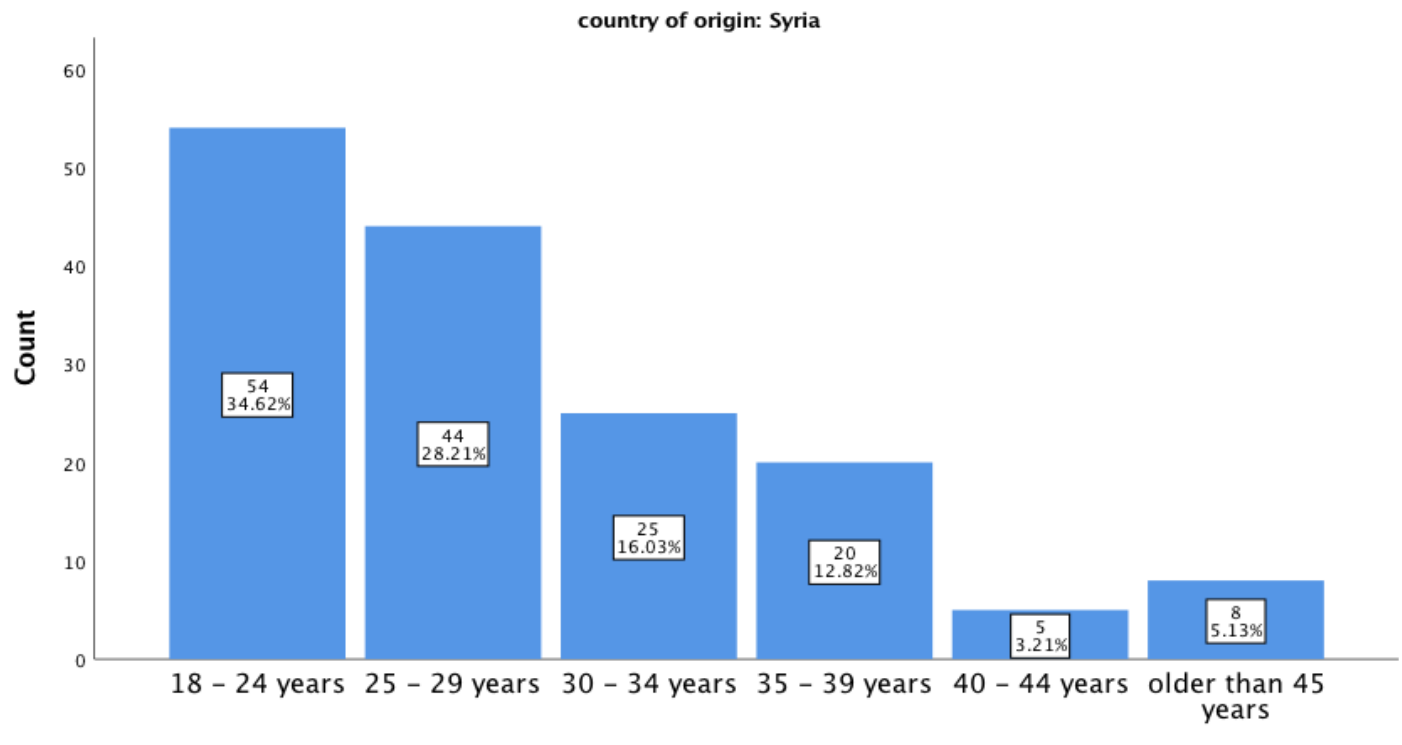

age

4: Age structure of refugees from Syria (in \%)

Source: author

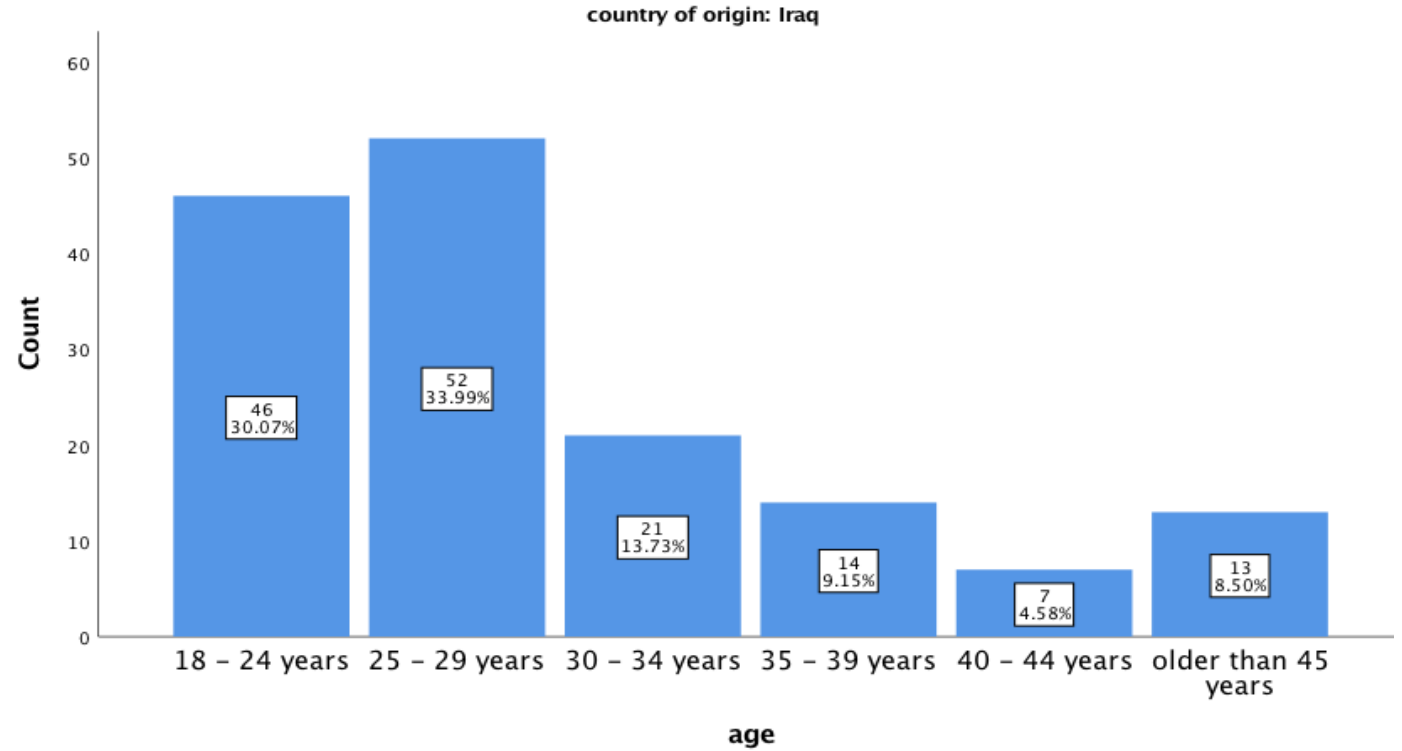

5: Age structure of refugees from Iraq (in \%)

Source: author

\section{School Education of Refugees from All Countries of Origin}

Fig. 7 shows the distribution of the highest schoolleaving qualifications for all countries of origin. $60.41 \%$ of refugees from all countries of origin attended primary and secondary school. A total of $14.3 \%$ have no formal school education. This shows a similar distribution to the results of the Federal Office for Migration and Refugees. The proportion of more highly educated refugees who have stated a secondary school leaving certificate or a university degree in the survey is about 25\%, which is lower than in the results of the BAMF (here about 38\%).

\section{School Education of Refugees from Syria, Iraq and Afghanistan}

Fig. 8 shows the educational distribution for the three top countries of origin. These distributions are also very similar to the results of the BAMF. Thus, the educational level of the Syrians is higher than that of the Iraqis. The Afghans have the lowest proportion of highly educated refugees. At this point, the high proportion of Afghan refugees who have no formal school education (30.7\%) is particularly striking. 


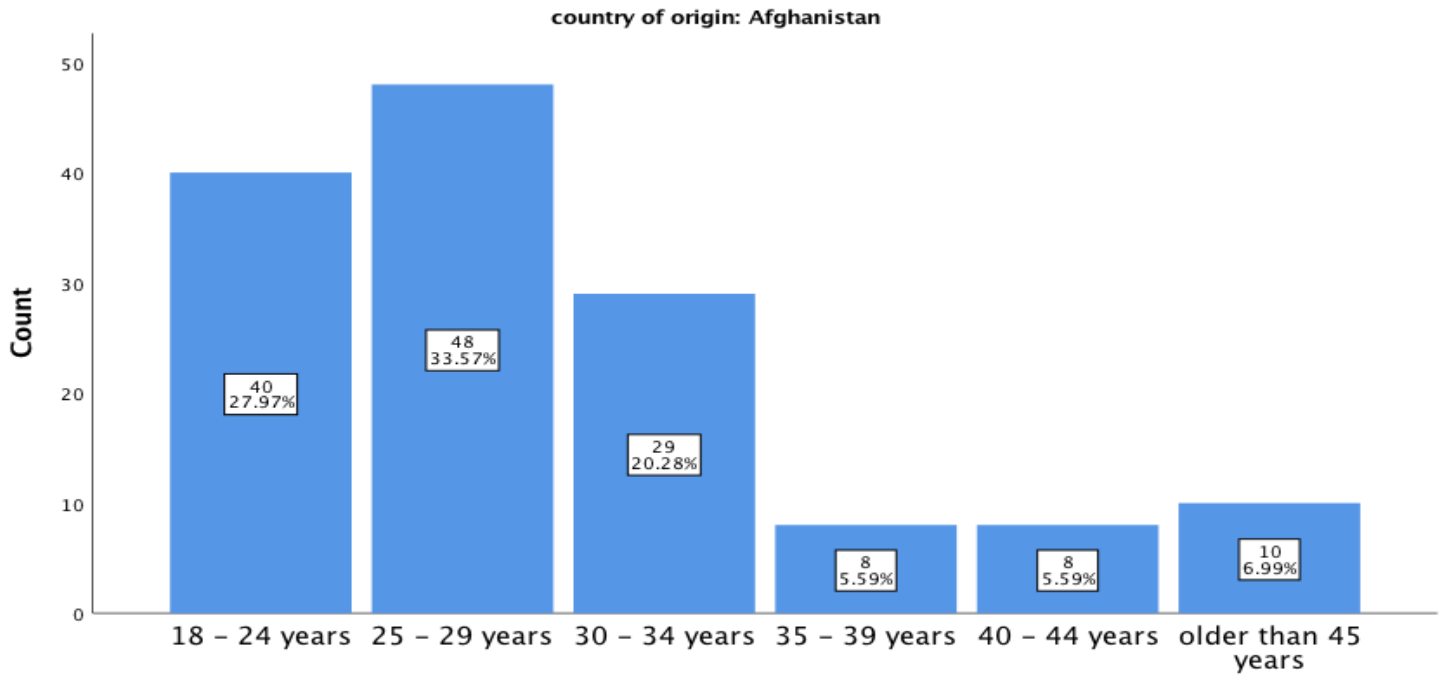

age

6: Age structure of refugees from Afghanistan (in \%)

Source: author

III: Age distribution of the top 3 countries of origin

\begin{tabular}{|c|c|c|c|c|c|c|c|c|}
\hline \multicolumn{2}{|c|}{$\begin{array}{l}\text { sex* age Crosstabulation }^{*} \\
\text { age in years }\end{array}$} & $18-24$ & $25-29$ & $30-34$ & $35-39$ & $40-44$ & 45 & Total \\
\hline \multicolumn{9}{|c|}{ Syria } \\
\hline \multirow{2}{*}{ Sex male } & Count & 29 & 26 & 14 & 10 & 3 & 4 & 86 \\
\hline & $\%$ within age & $53.7 \%$ & 59.1 & $56 \%$ & $50 \%$ & $60 \%$ & $50 \%$ & $55.1 \%$ \\
\hline \multirow{2}{*}{ Sex female } & Count & 25 & 18 & 11 & 10 & 2 & 4 & 70 \\
\hline & $\%$ within age & $46.3 \%$ & $40.9 \%$ & $44 \%$ & $50 \%$ & $40 \%$ & $50 \%$ & $44.9 \%$ \\
\hline \multirow{2}{*}{ Total } & Count & 54 & 44 & 25 & 20 & 5 & 8 & 156 \\
\hline & $\%$ within age & $100 \%$ & $100 \%$ & $100 \%$ & $100 \%$ & $100 \%$ & $100 \%$ & $100 \%$ \\
\hline \multicolumn{9}{|c|}{ Iraq } \\
\hline \multirow{2}{*}{ Sex male } & Count & 29 & 30 & 15 & 9 & 3 & 5 & 91 \\
\hline & $\%$ within age & $63 \%$ & $57.7 \%$ & $71.4 \%$ & $64.3 \%$ & $42.9 \%$ & $38.5 \%$ & $59.5 \%$ \\
\hline \multirow{2}{*}{ Sex female } & Count & 17 & 22 & 6 & 5 & 4 & 8 & 62 \\
\hline & $\%$ within age & $37 \%$ & $42.3 \%$ & $28.6 \%$ & $35.7 \%$ & $57.1 \%$ & $61.5 \%$ & $40.5 \%$ \\
\hline \multirow{2}{*}{ Total } & Count & 46 & 52 & 21 & 14 & 7 & 13 & 153 \\
\hline & $\%$ within age & $100 \%$ & $100 \%$ & $100 \%$ & $100 \%$ & $100 \%$ & $100 \%$ & $100 \%$ \\
\hline \multicolumn{9}{|c|}{ Afghanistan } \\
\hline \multirow{2}{*}{ Sex male } & Count & 31 & 36 & 21 & 5 & 8 & 8 & 109 \\
\hline & $\%$ within age & $77.5 \%$ & $75 \%$ & $72.4 \%$ & 62.5 & $100 \%$ & $80 \%$ & $76.2 \%$ \\
\hline \multirow{2}{*}{ Sex female } & Count & 9 & 12 & 8 & 3 & 0 & 2 & 34 \\
\hline & $\%$ within age & $22.5 \%$ & $25 \%$ & $27.6 \%$ & $37.5 \%$ & $0 \%$ & $20 \%$ & $23.8 \%$ \\
\hline \multirow{2}{*}{ Total } & Count & 40 & 48 & 29 & 8 & 8 & 10 & 143 \\
\hline & $\%$ within age & $100 \%$ & $100 \%$ & $100 \%$ & $100 \%$ & $100 \%$ & $100 \%$ & $100 \%$ \\
\hline
\end{tabular}

Source: author 


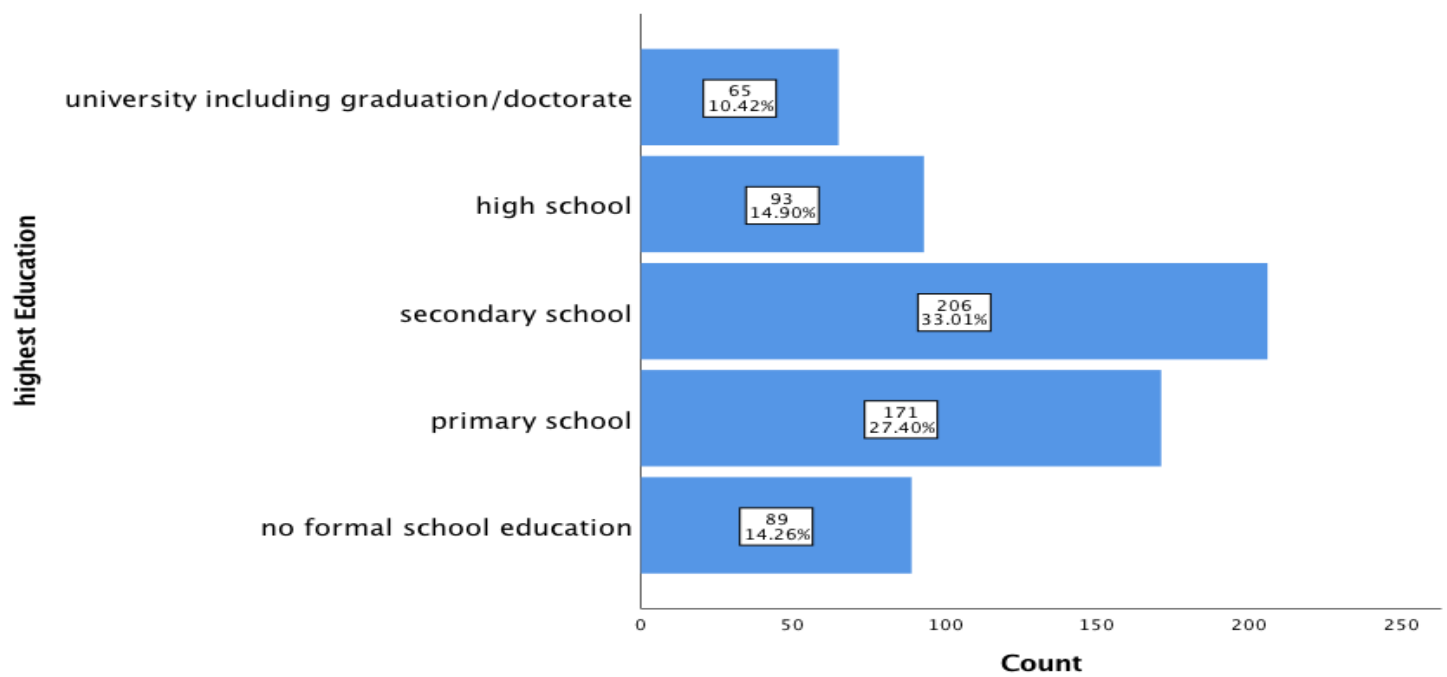

7: Highest educational level attended by refugees of all countries of origin (in \%) Source: author

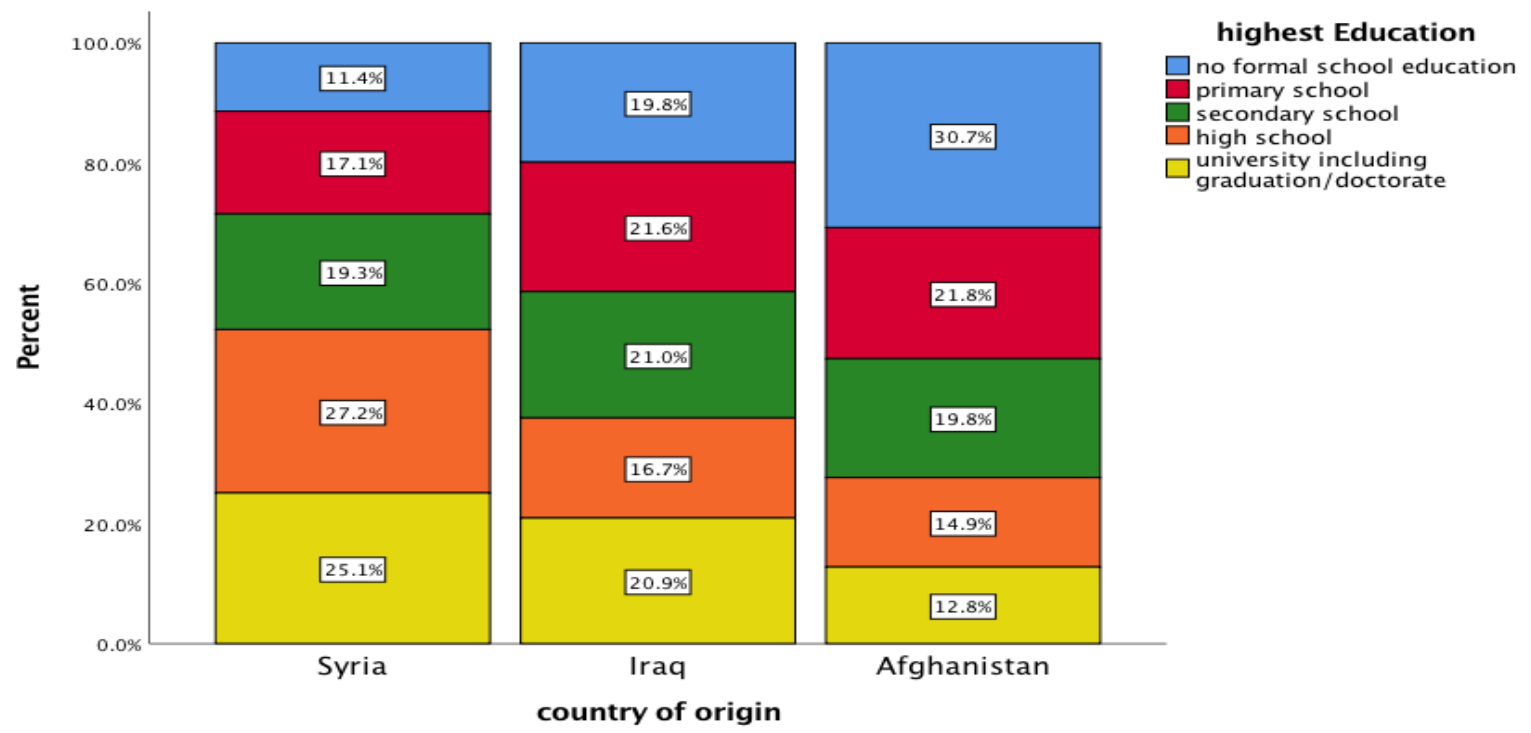

8: Highest educational level attended by refugees from the top 3 countries of origin (in \%) Source: author

IV: Highest vocational and university education of all countries of origin by gender (in \%)

\begin{tabular}{|c|c|c|c|c|c|}
\hline Training* sex & Crosstabulation sex & & Male & Female & Total \\
\hline \multirow{6}{*}{ Training } & \multirow{2}{*}{ No training } & Count & 288 & 180 & 468 \\
\hline & & $\%$ within sex & $71.5 \%$ & $81.4 \%$ & $75 \%$ \\
\hline & \multirow{2}{*}{ Company training } & Count & 67 & 24 & 91 \\
\hline & & $\%$ within sex & $16.6 \%$ & $10.9 \%$ & $14.6 \%$ \\
\hline & \multirow{2}{*}{$\begin{array}{l}\text { University including } \\
\text { graduation/doctorate }\end{array}$} & Count & 48 & 17 & 65 \\
\hline & & $\%$ within sex & $11.9 \%$ & $7.7 \%$ & $10.4 \%$ \\
\hline \multirow{2}{*}{ Total } & & Count & 403 & 221 & 624 \\
\hline & & $\%$ within sex & $100 \%$ & $100 \%$ & $100 \%$ \\
\hline
\end{tabular}

Source: author 
Vocational and University Education of Refugees from All Countries of Origin

In the case of training, both in-company and at university (Tab. IV), it can be seen that a high proportion did not undergo any training. This shows a slight overweight of men in each case. What is striking, however, is the high number of university degrees with a total of $10.4 \%$. Men are better educated than women in this area with $11.9 \%$.

\section{Vocational and University Education} of Refugees from Syria, Iraq and Afghanistan

Tab. V shows the results for the three top countries of origin. It can be seen that Syrian refugees have a proportionately high number of well-educated persons. Here, $31.4 \%$ of men have undergone incompany training and $10.5 \%$ have undergone university training. For women, $4.3 \%$ each have completed university or in-company training. It is striking that among Iraqi women the proportion of trained persons is higher than among Syrians. Overall, Afghans appear to be the worst educated.

To sum up, it can be seen that the various factors of the refugees described are widely scattered and that the qualifications of people from different countries of origin sometimes differ greatly from one another. The relatively high level of education provided by refugees from Syria, in contrast to other countries of origin, is particularly noteworthy, as they make up the vast majority of asylum seekers. However, the high proportion of people who do not have a formal school education or have only attended primary school remains to be noted. The high proportion of refugees with $75 \%$ who have no formal education is also conspicuous.

V: Highest vocational and university education of refugees of the top 3 countries of origin by gender (in \%)

\begin{tabular}{|c|c|c|c|c|c|}
\hline Training* sex & Crosstabulation sex & & Male & Female & Total \\
\hline \multicolumn{6}{|c|}{ Syria } \\
\hline \multirow{6}{*}{ Training } & \multirow{2}{*}{ No training } & Count & 50 & 64 & 114 \\
\hline & & $\%$ within sex & $58.1 \%$ & $91.4 \%$ & $73.1 \%$ \\
\hline & \multirow{2}{*}{ Company training } & Count & 27 & 3 & 30 \\
\hline & & $\%$ within sex & $31.4 \%$ & $4.3 \%$ & $19.2 \%$ \\
\hline & \multirow{2}{*}{$\begin{array}{l}\text { University including } \\
\text { graduation/doctorate }\end{array}$} & Count & 9 & 3 & 12 \\
\hline & & $\%$ within sex & $10.5 \%$ & $4.3 \%$ & $7.7 \%$ \\
\hline \multirow{2}{*}{ Total } & & Count & 86 & 70 & 156 \\
\hline & & $\%$ within sex & $100 \%$ & $100 \%$ & $100 \%$ \\
\hline \multicolumn{6}{|c|}{ Iraq } \\
\hline \multirow{6}{*}{ Training } & \multirow{2}{*}{ No training } & Count & 77 & 52 & 129 \\
\hline & & $\%$ within sex & $84.6 \%$ & $83.9 \%$ & $84.3 \%$ \\
\hline & \multirow{2}{*}{ Company training } & Count & 9 & 6 & 15 \\
\hline & & \% within sex & $9.9 \%$ & $9.7 \%$ & $9.8 \%$ \\
\hline & \multirow{2}{*}{$\begin{array}{l}\text { University including } \\
\text { graduation/doctorate }\end{array}$} & Count & 5 & 4 & 9 \\
\hline & & $\%$ within sex & $5.5 \%$ & $6.5 \%$ & $5.9 \%$ \\
\hline \multirow{2}{*}{ Total } & & Count & 91 & 62 & 153 \\
\hline & & $\%$ within sex & $100 \%$ & $100 \%$ & $100 \%$ \\
\hline \multicolumn{6}{|c|}{ Afghanistan } \\
\hline \multirow{6}{*}{ Training } & \multirow{2}{*}{ No training } & Count & 89 & 31 & 120 \\
\hline & & $\%$ within sex & $81.7 \%$ & $91.2 \%$ & $83.9 \%$ \\
\hline & \multirow{2}{*}{ Company training } & Count & 15 & 3 & 18 \\
\hline & & $\%$ within sex & $13.8 \%$ & $8.8 \%$ & $12.6 \%$ \\
\hline & \multirow{2}{*}{$\begin{array}{l}\text { University including } \\
\text { graduation/doctorate }\end{array}$} & Count & 5 & 0 & 5 \\
\hline & & $\%$ within sex & $4.6 \%$ & $0 \%$ & $3.5 \%$ \\
\hline \multirow{2}{*}{ Total } & & Count & 109 & 34 & 143 \\
\hline & & \% within sex & $100 \%$ & $100 \%$ & $100 \%$ \\
\hline
\end{tabular}

Source: author 


\section{DISCUSSION}

It has been shown that about $70 \%$ of asylum seekers from the years 2015-2017 are of working age. $41.7 \%$ of asylum seekers have no schoolleaving qualifications or only primary school knowledge. Also noteworthy here is the high proportion of people who have no education (75\% of asylum seekers). These assumptions are confirmed by the results of the Microcensus 2016 of the Federal Statistical Office (Statista, 2016). The low qualification level of the refugees leads to a high rush of these persons in the low-wage sector. Thus, according to an assessment by the Federal Employment Agency, more than 60\% of job-seeking refugees can only be considered for assistance activities (BA, 2017, p. 11). The high number of men also suggests that in the coming years the families and relatives of the refugees entitled to stay will follow, which will further reduce the educational average. The educational average for women from all countries of origin is much lower than for men. This is due in particular to family obligations due to the traditional family structure, especially among Muslims.

In order to address existing shortcomings, existing training programs must be used consistently. However, a serious backlog, as it is evident in many areas, is difficult to make up, especially if the corresponding language skills are lacking. Insufficient language skills and inadequate qualification levels of refugees are seen by German employers as major barriers to recruitment (Gürtzgen et al., 2017).

\section{CONCLUSION}

The refugee crisis of recent years is one of the greatest tasks for both the Federal Republic of Germany and the European Union. The high number of asylum seekers will bring about many social, political and economic changes. In this article, the educational structure of refugees has been explicitly considered. In the course of a survey of refugees and a comparative analysis with the data of the Federal Office for Migration and Refugees, it was established that refugees are poorly educated both at school and at work.

An important and central component in coping with the refugee crisis is therefore of a political and institutional nature. Integrative measures and continuing education offerings are of great relevance, especially for the majority of refugees who have no education, given the established educational structure of refugees. The quality and implementation of these measures, which are intended to ensure that refugees willing to work receive further training and enter the labour market, are thus primarily decisive for the success of the integration of refugees into the labour market. The key to integrating young asylum seekers with formal schooling into the labour market quickly and on a long-term basis is therefore to provide them with training that is tailored to their needs and also to integrate them into the training market. Corresponding measures should be evaluated in the short and long term in order to be able to make any necessary adjustments. The family reunification of refugees and the further admission of refugees and migrants should also be considered. It is particularly important at this point how this will ultimately be organised and how many more refugees will arrive in the Federal Republic of Germany.

\section{REFERENCES}

AUMÜLLER, J. and GESEMANN, F. 2016. Refugees to the Rural Area? Migration and integration in rural areas [in German: Flüchtlinge aufs Land? Migration und Integration im ländlichen Raum]. Zeitschrift Politik und Zeitgeschichte, 11: 29-34.

BA. 2017. Reports: Labour market compact 2017. Refugee migration [in German: Berichte: Arbeitsmarkt kompakt 2017. Fluchtmigration]. Nürnberg: Statistik der Bundesagentur für Arbeit.

BA. 2018. Skilled labour bottleneck analysis. Reports: Focus on the labour market [in German: Fachkräfteengpassanalyse. Berichte: Blickpunkt Arbeitsmarkt]. Nürnberg: Bundesagentur für Arbeit.

BAMF. 2015. Asylum business report for the month December 2015 [in German: Asylgeschäftsbericht für den Monat Dezember 2015]. Nürnberg: Bundesamt für Migration und Flüchtlinge.

BAMF. 2016. Asylum business report for the month December 2016 [in German: Asylgeschäftsbericht für den Monat Dezember 2016]. Nürnberg: Bundesamt für Migration und Flüchtlinge.

BAMF. 2017. Asylum business report for the month December 2017 [in German: Asylgeschäftsbericht für den Monat Dezember 2017]. Nürnberg: Bundesamt für Migration und Flüchtlinge.

BROSSARDT, B. and EHRENTRAUT, O. 2015. Work Environment 2014 [in German: Arbeitslandschaft 2014]. Studie der Prognos AG im Auftrag der Vereinigung der Bayerischen Wirtschaft e. V. München.

BRÜCKER, H., MÖLLER, J. and WOLFF, J. 2016. Integration of refugees [in German: Integration von Geflüchteten]. IAB-Stellungnahme No. 4. Nürnberg: Institut für Arbeitsmarkt-und Berufsforschung. 
BRÜCKER, H., ROTHER, N. and SCHUPP, J. 2018. IAB-BAMF-SOEP survey of fugitives 2016: study design, field results and analyses of school and vocational qualifications, language skills and cognitive potential [in German: IAB-BAMF-SOEP-Befragung von Ge-flüchteten 2016: Studiendesign, Feldergebnisse sowie Analysen zu schulischer wie beruflicher Qualifikation, Sprachkenntnisse sowie kognitiven Potenzialen]. Forschungsbericht 30. Nürnberg: Bundesamt für Migration und Flüchtlinge.

GÜRTZGEN, N., KUBIS, A. and REBIEN, M. 2017. Refugees are arriving more and more on the labour market [in German: Geflüchtete kommen mehr und mehr am Arbeitsmarkt an]. IAB-Kurzbericht 14/201. Nürnberg: Institut für Arbeitsmarkt- und Berufsforschung.

NESKE, M. 2017. Asylum seekers of full age in Germany in 2016. Social structure, qualification level and professional activity [in German: Volljährige Asylantragsteller in Deutschland im Jahr 2016. Sozialstruktur, Qualifikationsniveau und Berufstätigkeit]. Kurzanalysen des Forschungszentrums Migration, Integration und Asyl. No. 2. Nürnberg: Bundesamt für Migration und Flüchtlinge.

RICH, A.-K. 2016. Asylum seekers in Germany in 2015. Social structure, qualification level and professional activity [in German: Asylantragsteller in Deutschland im Jahr 2015. Sozialstruktur, Qualifikationsniveau und Berufstätigkeit]. Kurzanalysen des Forschungszentrums Migration. Integration und Asyl. No. 3. Nürnberg: Bundesamt für Migration und Flüchtlinge.

SCHMIDT, H.-J. 2018. Asylum seekers of full age in Germany in 2017: social structure, school attendance and employment in the country of origin [in German: Volljährige Asylerstantragsteller in Deutschland im Jahr 2017: Sozialstruktur, Schulbesuch und Berufstätigkeit im Herkunftsland]. Kurzanalysen des Forschungszentrums Migration, Integration und Asyl. No. 3. Nürnberg: Bundesamt für Migration und Flüchtlinge.

STATISTA. 2016. Population and employment. Population with a migrant background. Results of the microcensus [in German: Bevölkerung und Erwerbstätigkeit. Bevölkerung mit Migrationshintergrund. Ergebnisse des Mikrozensus]. Professional series 1 (2.2). Wiesbaden: Statistisches Bundesamt.

Contact information

Katja Stammen: katja91169@web.de 